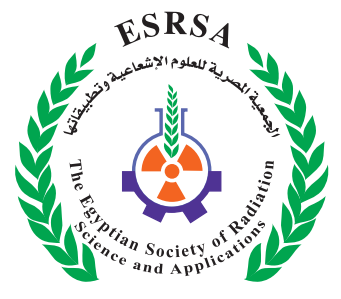

J. Nucl. Tech. Appl. Sci., Vol. 8, PP. 49 : 65 (2020)

\title{
Biocontrol Mechanisms of Bacillus sp. and its Application as a Bionanocomposite against Rhizoctonia solani
}

Maghrawy, H.H. ${ }^{1}$; Gomaa, O.M. ${ }^{1}$; ElGizawy, S. ${ }^{2}$, Refae, R.I. ${ }^{2}$ and Abd El Kareem, H. ${ }^{1}$

Received: $13 / 01 / 2020$

Accepted: 08/04/2020

E.mail:hoba_magrawy@yahoo.com

\section{KEYWORDS}

Antifungal activity; Bacillus sp.; Rhizoctonia solani; biocontrol; mechanism of action, bionanocomposite.

\section{ABSTRACT}

Black scurf disease caused by Rhizoctonia solani is a main yield limiting factor for potato tuber production as it leads to plant death. Using chemical treatment is not economic, therefore, the present study aimed to isolate naturally occurring antagonistic bacteria that could control R. solani. Bacillus sp. was selected among of 84 isolates secured from rhizosphere of healthy potato plant based on its ability to suppress the growth of the pathogen $R$. solani. Phylogenetic analysis of this strain based on 16S rRNA gene sequences showed highest similarity (99\%) with Bacillus sp.; it was deposited in the GenBank under the accession number of MK030136. The strain culture filtrate containing protease, diffusible antibiotic, hydrogen cyanide and siderophore was capable of inhibiting growth of the pathogen up to 15 days compared to 7 and 10 days for other Bacillus isolates. It also produces indole acetic acid which promoted plant growth. Morphological and structural changes that took place as a result of Bacillus sp. and $R$. solani interaction were evaluated using light, scanning and transmission electron microscopies. The results showed that Bacillus sp. caused loss of structural integrity, abnormal coiling, shriveling and lysis of the $R$. solani hyphae, in addition to complete cytoplasm and internal organelles depletion. The Bacillus sp. under study was immobilized on nanoclay to form a bionanocomposite, which was stable and exhibited the biocontrol efficiency along 8 months storage. Both in vitro and greenhouse experiments showed high inhibition

1. Radiation Microbiology Department, National Center for Radiation Research and Technology, Egyptian Atomic Energy Authority, Cairo, Egypt.

2. Microbiology Department, Faculty of Agriculture, Cairo University. Giza, Cairo, Egypt. 
of $R$. solani radial growth. Results indicate that the prepared bionanocomposite is a promising alternative to the commercial products.

\section{INTRODUCTION}

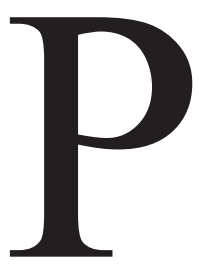

otato is the third most important food crop in the world after rice and wheat in terms of human consumption (FAO, 2014). It is the world's fourth produced food product, it has the ability to grow in a wide range of climatic conditions, it is highly nutritive and contains high number of vitamins, minerals, proteins, antioxidants, essential amino acids and carbohydrates (FAO, 2009). The Food and Agriculture Organization (FAO) emphasizes on the significant role potatoes play in the world global food system. It is important to maintain a healthy produce in terms of quality and quantity since potatoes provide food, feed and fibre. All of which are needed to sustain the health requirements of a rapidly growing population (Shafi et al., 2017). One of the many problems surrounding potato cultivation that affect the potato economic yield on a global, national and individual farmer level is fungal pathogenesis. Black scurf is one of the critical diseases caused by the fungus Rhizoctonia solani. Once this fungus is present in the soil, it is difficult to control due to its broad host range, saprophytic life cycle and persistence of the sclerotia and mycelium in soil and plant material (Ajayi-Oyetundea and Bradley, 2018). Within a few years, this plant disease causes the loss of about $34 \%$ of the produce in addition to changes in size and distribution of tubers (Kumar et al., 2017). This problem is a worldwide and is usually addressed by chemical -based-pesticides and fertilizers (Shafi $\boldsymbol{e t}$ al., 2017). However, the use of chemical pesticides leads to an increase in production cost, health hazards, environmental pollution and pesticide residual effects on human health and soil ecosystem. In addition to the development of resistant pathogens due to prolonged exposure to antifungal chemicals. An alternative to chemical pesticides is the use of biological control that entails applying microbial cells or their metabolites to attack fungal pathogens (Tortora et al., 2011; Nandi et al., 2017). Several mechanisms of action are thought to be involved in the process of biological control, all of which are based on ecological interactions, such as competition for space and nutrients, parasitism (production of hydrolytic enzyme such as proteases, cellulases and chitinases), antibiosis and induction of plant defenses (Jamalizadeh et al., 2011). Many microorganisms were reported to have fungal antagonistic activity and can be used as biocontrol agents. The use of $\mathrm{Ba}$ cillus sp. has increased due to its ability to replicate rapidly, form endospores, tolerate extreme $\mathrm{pH}$, temperature and osmotic conditions as well as produce several antibiotics, siderophores and hydrolytic enzymes (Chaurasia et al., 2005). In order to maintain viability and efficiency of a biocontrol agent, the delivery system is prepared as a formulation where the cells are immobilized on a support (Ma $\boldsymbol{e t} \boldsymbol{a l}$., 2015). Immobilization of cells on nanoparticles provides advantages over traditional support materials, it increases mass transfer and minimizes diffusion limitation. Therefore, the aim of this study is to isolate bacteria with efficient biocontrol activity against Rhizoctonia solani, depict its mechanism of action and test its efficacy as a bionanocomposite in vitro and in green house.

\section{MATERIALS AND METHODS}

\section{Collection of soil samples}

Four cultivated soil samples were collected in sterile plastic bags from the rhizosphere of healthy plants of potato from four Egyptian governorates: Sharkia, Giza, Beheira and Menofia. The rhizosphere was ditch with intact root system. Samples were air dried for $24 \mathrm{~h}$ at ambient temperature before use. 


\section{Isolation of bioantagonistic bacteria and}

Rhizoctonia solani

Ten grams of each soil sample were transferred into $250 \mathrm{ml}$ conical flask containing $90 \mathrm{ml}$ of sterilized saline solution, and shaken for $1 \mathrm{~h}$ at $150 \mathrm{rpm}$. The resulting soil suspension was serially diluted up to $10^{-7}, 0.1 \mathrm{ml}$ of each dilution was plated onto nutrient agar medium, plates were incubated at $30^{\circ} \mathrm{C}$ for $48 \mathrm{~h}$. Developed colonies were picked up, purified through streaking plate method and sub-cultured on Luria Bertani agar medium slants. A total of 84 purified isolates was screened for antifungal activity against the isolated pathogenic Rhizoctonia solani from potato plant (Lady rossetta) that showed symptoms of $R$. solani disease. Pieces of potato tubers were submerged in 5\% sodium hypochloride for five minutes then washed with sterile distilled water and placed on Petri dishes containing potato dextrose agar (PDA) and incubated at $22^{\circ} \mathrm{C}$ for five days. Fifty $\mu \mathrm{l}$ of $24 \mathrm{~h}$ old bacterial suspensions obtained from different samples were placed on sterile paper disks. Disks were placed on Petri dishes containing PDA surrounding $10 \mathrm{~mm}$ diameter disk containing the mycelium of $R$. solani placed in the center of plates which were incubated at $30{ }^{\circ} \mathrm{C}$ for 7 days. The inhibition of mycelium growth was checked and was repeated three times. Results are expressed as percentage of growth inhibition of $R$. solani in the presence of the bacterial isolates. The percent growth inhibition (PGI) was calculated using the following formula:

$$
P G I(\%)=\frac{K R-R I}{K R} \times 100
$$

Where: KR represents the distance (measured in $\mathrm{mm}$ ) from the point of inoculation to the colony margin on the control Petri plate, and R1 is the distance of fungal growth from the point of inoculation to the colony margin on the treated Petri plate in the direction of the antagonist (Raupach and Kloepper,
1998). The zone of inhibition was recorded as the distance between the fungal pathogen and the area of antagonist growth after 7 days. Based on the results of antagonistic activity, 3 isolates were selected for further studies.

\section{Bioproducts from Bacillus isolates that affecting the growth of $R$. solani}

\section{Hydrolytic enzymes}

The three isolates were screened for their abilities to produce hydrolytic enzymes that can degrade polymeric compounds including chitin, proteins, amylase, lipase and cellulase by adopting the agar plate screening. The isolates were grown on Luria Bertani agar supplemented with substrates for each enzyme as $1 \% \mathrm{w} / \mathrm{v}$ casein, $0.2 \%$ carboxymethyl cellulose, $2 \%$ colloidal chitin, $1 \%$ Tween 20 and $2 \%$ w/v soluble starch as substrates for protease, cellulase, chitinase, lipase and amylase, respectively. The five $\mathrm{mm}$ plug of each isolate was placed at the center of each enzyme screening agar plate and incubated at $30^{\circ} \mathrm{C}$ for $24 \mathrm{~h}$. Colonies which exhibited surrounding clear zone were considered as positive results for enzyme production (Thakaew and Niamsup, 2013). Each experiment was performed in three replicates.

\section{Volatile antifungal compounds}

To verify the production of volatile compounds by the isolates, a culture disk ( $5 \mathrm{~mm}$ in diameter) of the isolates was placed at the center of one half Petri plate containing nutrient agar and $5 \mathrm{~mm}$ disk of a 4- day old culture of $R$. solani was placed at the center of another Petri plate containing PDA. Both half plates were placed face to face preventing any physical contact between the bacteria and the pathogen, and were sealed with paraffin film to prevent loss of volatiles formed (Montealegre et al., 2003)

\section{Diffusible antifungal compounds}

Antagonistic activities of the extracts were tested by agar well diffusion method (Shanmuga et al., 
2002). PDA medium $(20 \mathrm{~mL})$ was poured into each sterile Petri dish, followed by placement of mycelial disk ( $5 \mathrm{~mm}$ in diameter) of the $R$. solani at the center of the plates. A well ( $5 \mathrm{~mm}$ in diameter) was made by punching the agar with a sterile steel borer at a distance of $3 \mathrm{~cm}$ from the central $5 \mathrm{~mm}$ fungal inoculum. Each Bacillus isolate was cultivated in $50 \mathrm{ml}$ nutrient broth and incubated without shaking at $30^{\circ} \mathrm{C}$ for $72 \mathrm{~h}$. Ten $\mathrm{ml}$ aliquots were withdrawn from each flask, centrifuged at $6000 \mathrm{rpm}$ for $20 \mathrm{~min}$. The supernatant was collected and filtered through millipore membrane $(0.22 \mu \mathrm{m})$ and $50 \mu \mathrm{l}$ of each extract were poured into the well and one well was used as a control. The plates were incubated at $30^{\circ} \mathrm{C}$ for 7 days.

\section{Siderophore production}

Bacillus isolates were cultivated on blue agar medium at $30^{\circ} \mathrm{C}$ for $24 \mathrm{~h}$ (Adhikari et al., 2013). An orange halo surrounding bacterial colonies indicated siderophore production.

\section{HCN determination}

HCN production test was performed as described by Kumar et al. (2012). Bacteria were heavily inoculated in nutrient agar plates and incubated in an inverted position at $30^{\circ} \mathrm{C}$ for $24 \mathrm{~h}$ with filter paper strips dipped in picric acid placed inside the lids. Change of color of the indicator strip from yellow to brown was considered as a positive result.

\section{Production of the plant growth promoting phytohormone IAA.}

Production of IAA (indole -3-acetic acid) was determined according to Patten and Glick (2002). $24 \mathrm{~h}$ old bacterial cultures grown on Luria-Bertani (LB) broth supplemented with L-tryptophane were centrifuged at $6000 \mathrm{rpm}$ for $20 \mathrm{~min}$ to obtain culture supernatants. The supernatants $(1 \mathrm{ml})$ were mixed vigorously with $4 \mathrm{ml}$ Salkowskis reagent (Gordon and Weber., 1951). Development of pink color indicated a positive result.

\section{Dual culture of isolates and pathogen for long incubation period}

To confirm the ability of the isolates for fungicidal action, dual cultures were prepared with $R$. solani and each of the three isolates. A $5 \mathrm{~mm}$ disk of pathogen mycelium and 5-mm round filter papers were wet with $50 \mu 1$ of bacterial suspension. The filter paper and pathogen disk were placed opposite to each other on a potato dextrose agar (PDA) plate and incubated at $30^{\circ} \mathrm{C}$ in the dark for 3 days, during which the growth margins were inspected regularly. The diameters of inhibition areas on the PDA plates were recorded up to 15 days (Yang and Sung, 2011).

\section{Identification of biocontrol active isolates}

The isolates were characterized by morphological and biochemical tests according to Bergey's Manual of Systematic Bacteriology (Sneath et al., 1986). The isolate that displayed 15 days of inhibition was subjected to $16 \mathrm{~S}$ rRNA phylogenetic identification. DNA of a $24 \mathrm{~h}$ culture was extracted in $1 \mathrm{ml}$ TE buffer ( $\mathrm{pH}$ 8). The cell suspension was boiled for $10 \mathrm{~min}$ to release DNA then chilled on ice for $10 \mathrm{~min}$. The suspension was centrifuged at $10,000 \mathrm{rpm}$ for $5 \mathrm{~min}$. About $50 \mathrm{ng}$ of DNA template was added to $45 \mu \mathrm{l}$ of PCR reaction solution (Macro Gen) using the following primer sets 27-8 GAGTTTGATCCTGGCTCAG and 1492 GGTTACCTT GTTACGA (Edwards $\boldsymbol{e} t$ al., 1989). The amplification was performed as follows: 35 amplification cycles at $94^{\circ} \mathrm{C}$ for $45 \mathrm{sec}, 55^{\circ} \mathrm{C}$ for $60 \mathrm{sec}$ and $72^{\circ} \mathrm{C}$ for $60 \mathrm{sec}$. An aliquot of 5-15 $\mu 1$ of PCR reaction products was electrophoresed on a $1 \%$ agarose gel containing ethidium bromide (10 $\mathrm{mg} / \mathrm{ml}$ in $\mathrm{dH}_{2} 0$ ) and the DNA bands were visualized under the UV light. The amplified PCR products were submitted to Solgent Co Ltd (South Korea) for purification and sequencing. The resulted sequences were trimmed and assembled in Geneious software (Biomatters).The sequence was compared to the NCBI nucleotide database (www.ncbi.nih.gov/blst) 
and phylogentic tree of the strain given an accession number MK030136 was constructed based on the 16s-rRNA sequence comparisons length polymorphism of the PCR-amplified and sequences from database using blast tree construct in (https://blast.ncbi. nlm.nih.gov/blast/treeview/treeView.cgi).

Light, scanning electron (SEM) and transmission electron microscopy (TEM) studies for antagonistic effects of Bacillus sp. on mycelia morphology of $R$. solani.

For light microscopy, $R$. solani cultures before and after treatment with Bacillus sp. were mounted on clean glass slides and stained using Lactophenol cotton blue dye. Slides were examined using 40X lens. The antagonistic properties of Bacillus sp. were studied using SEM (Kumar et al., 2013). Plugs of mycelium ( $1 \mathrm{~mm}$ in diameter) cut from the fungal mycelia growing towards the inhibition zone were managed for SEM by the following procedure: agar discs placed on cover glasses were treated with 2 $\%$ osmium tetra oxide vapors for $24 \mathrm{~h}$ at $20^{\circ} \mathrm{C}$. The treated samples were attached to aluminum stubs with double adhesive tape, coated with gold, and then captured using JOEL JMS 5600 scanning electron microscope. Mycelial growth in control plates was observed and compared with the hyphal deformities near the inhibition zone. For TEM assay, cells were infiltered with acetone for $24 \mathrm{~h}$ and polymerized at $60^{\circ} \mathrm{C}$ for $48 \mathrm{~h}$. Fifty nanometer sections were sectioned, then the sections were placed on copper sieves and contrasted with uranyl acetate and lead citrate for 30 min each (Zhang et al., 2013), the sections were viewed on JEOL-JEM 1010 TEM.

\section{Bionanocomposite experiments:}

\section{Immobilization of Bacillus sp. on nanoclay particles}

Bacillus sp. cells were initially cultured for 24 $\mathrm{h}$ at $30^{\circ} \mathrm{C}$. Ten $\mathrm{ml}$ of the preculture (ca. $6 \times 10^{7} \mathrm{CFU} /$
$\mathrm{mL}$ ) were transferred into $10 \mathrm{mg}$ of clay nanoparticles (bentonite) obtained from Medical Export Company (UK) and cultivated for $72 \mathrm{~h}$ at $30^{\circ} \mathrm{C}$ under static conditions. Immobilization of bacterial cells was characterized by scanning electron microscopy (JOEL JMS 5600), X-Ray diffraction (6000 SHIMADZU), the dried powder of bionanocomposite homogenized was pressed in a stainless-steel sample holder for collecting the XRD patterns using $\mathrm{CuK} \alpha$ radiation operating at $40 \mathrm{kV}$ and $40 \mathrm{~mA}$. Fourier Transform Infrared Spectroscopy (FT-IR) scanning was performed from 400 to $4000 \mathrm{~nm}$ using FTIR, BRUKER VERTEX 70 device

\section{Shelf life of bionanocomposite and its antagonistic activity during storage time}

The viability of Bacillus sp. on clay nanoparticles was examined monthly up to 8 months using the dilution plate method. Plates were incubated at $30^{\circ} \mathrm{C}$ for $24 \mathrm{~h}$ and the bacterial population was determined. Ten $\mu 1$ of bionanocomposite solution (2.7.1) stored at room temperature ( 8 months) were inoculated at the opposite side of PDA plates and incubated with $6 \mathrm{~mm}$ diameter of $R$. solani as previously mentioned (Isolation of bioantagonistic bacteria and Rhizoctonia solani)

\section{Evaluation of bionanocomposite antagonistic activity against $R$. solani.}

The experiments were carried out during the growing season 2019. Sterilized plastic pots $(20 \mathrm{~cm}$ in diameter), each contains $3 \mathrm{Kg}$ of sterilized soil were infested with $R$. solani grown on sand corn meal medium at the rate of $5 \%$ soil weight. Pots were watered regularly for 10 days before planting to insure distribution of inoculum. Since the Lady Roseta cultivar is one of the most sensitive cultivars, it was selected for greenhouse experiment. Healthy potato tubers seeds (cv. Lady Rosetta- susceptible) having about four eyes (buds) and uniform in size and weight possible were selected and washed to 
remove existing soil, surface sterilized in $2.0 \%$ sodium hypochlorite solution for $3 \mathrm{~min}$; rinsed 3 times in sterile distilled water then air dried (Tariq et al., 2010). Sterilized tubers were sown at the rate of 3 tubers / pot. Tubers were dipped in either 5L of bionanocomposite suspension or Bio Arc commercial formulation (6\%) purchased from Central Agriculture Pesticide Laboratory of A.R.C. The immersion time for both treatments was $0,10,20,30$ and 60 min. Data were recorded after 60 days of planting using non-soaked tuber (negative control) and Bio Arc soaked tubers (positive control) in infested soil as controls. The reduction of disease incidence was calculated according to the following formula: disease incidence $\%=$ number of infected plant /total number of plants assessed $\times 100$. Plant heights as well as fresh and dry weights were also recorded at the end of the experiment.

\section{Statistical analysis}

Statistical analysis was performed using oneway analysis of variance (ANOVA) by Minitab software (version 17). P-Value $<0.05$ considered as significant.

\section{RESULTS}

\section{Characteristics of $R$. solani}

$R$. solani used in the antagonism was isolated from the infected parts of Lady Rossetta potato plant. Pure culture of isolated fungus was identified according to the cultural properties, morphological and microscopical characteristics (Fig 1). Results showed that $R$. solani slightly melanized hyphae and irregularly shaped. Microscopic observation revealed that the hyphae branched at a $90^{\circ}$ angle, constriction of hyphae, formation of septa at a short distance from the point of the hyphal branches' origins and absence of clamp connection and conidia (Ajayl-Oyetunde and Bradley, 2018).
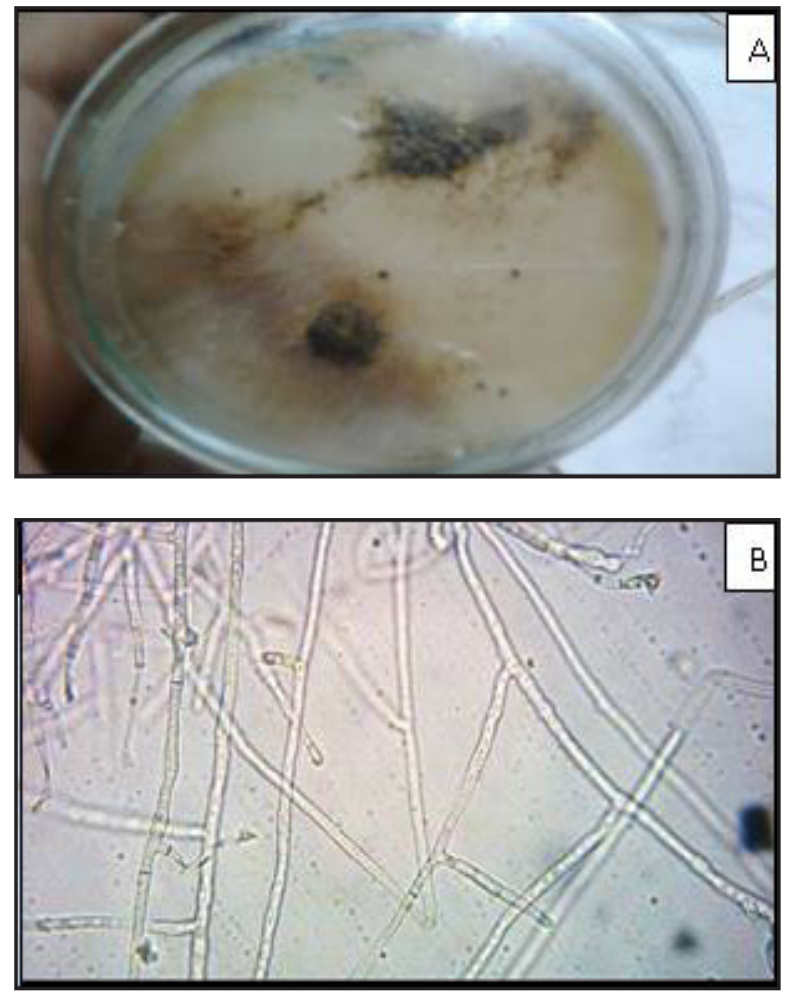

Fig. (1): $R$. solani grown on PDA (A) and under light microscope (B).

\section{Antifungal activity of bacterial isolates}

Table (1) represents 84 isolates screened for their ability to suppress the growth of $R$. solani. Results show that the antifungal activity was variable and ranged from 11 to $83 \%$. Three isolates exhibited the highest inhibition properties $(78,82$ and 83 $\%$ ) against $R$. solani were isolated from Beheira and Giza.

\section{Bioproducts from bacterial isolates}

As shown in Table (2), all bacterial isolates were negative for chitinase, lipase, amylase, cellulase or volatile antibiotics. However, the extracellular enzyme protease was detected only with isolate B1. Other secondary antifungal compounds e.g. diffusible and volatile antibiotics, siderophores, $\mathrm{HCN}$ and IAA were detected by both B1 and B3 isolates. 
Table (1) : Screening of antagonistic properties of bacteria isolated from rhizosphere of different Governor ates on R. Solani.

\begin{tabular}{|c|c|c|c|}
\hline \multicolumn{2}{|c|}{ Governorate (number of isolates) } & Fungal radical growth (mm) & \%Average of inhibition \\
\hline \multirow{4}{*}{ Giza (23) } & $\mathbf{1}$ & $\mathbf{1 5 - 2 0}$ & $\mathbf{8 3}$ \\
\cline { 2 - 4 } & 5 & $<40-55$ & $50-67$ \\
\cline { 2 - 4 } & 2 & $60-80$ & $33-44$ \\
\cline { 2 - 4 } & 14 & - & 0 \\
\hline \multirow{4}{*}{ Beheira (22) } & $\mathbf{2}$ & $\mathbf{1 5 - 2 0}$ & $\mathbf{7 8 - 8 2}$ \\
\cline { 2 - 4 } & 5 & $.40-55$ & $39-50$ \\
\cline { 2 - 4 } & 7 & $60-80$ & $11-33$ \\
\hline \multirow{4}{*}{ Sharkia (21) } & 8 & - & 0 \\
\cline { 2 - 4 } & - & $15-20$ & - \\
\cline { 2 - 4 } & 5 & $-40-55$ & $39-55$ \\
\cline { 2 - 4 } & 4 & $60-80$ & $11-33$ \\
\hline \multirow{3}{*}{ Menofia (18) } & - & - & 0 \\
\cline { 2 - 4 } & 6 & $15-20$ & - \\
\cline { 2 - 4 } & 4 & $<40-55$ & $39-50$ \\
\hline
\end{tabular}

Table (2) : Characterization of antifungal compounds produced by bacterial isolates B1, B2 and B3.

\begin{tabular}{|l|c|c|c|}
\hline Isolates & B1 & B2 & B3 \\
\hline Chitinase & - & - & - \\
\hline Protease & + & - & - \\
\hline Lipase & - & - & - \\
\hline Amylase & - & - & - \\
\hline Cellulase & - & - & + \\
\hline Diffusible antibiotic & + & + & - \\
\hline Volatile antibiotic & - & - & + \\
\hline Siderophores & + & - & - \\
\hline Hydrogen Cyanide & + & - & - \\
\hline Indole Acetic Acid & + & - & \\
\hline
\end{tabular}

+ , positive result: -, negative result.

\section{Identification of antagonistic bacterial isolates}

According to Bergey's Manual of Systematic Bacteriology (Sneath et al, 1983), the three isolates with the highest inhibition zones belonged to the genus Bacillus (Table, 3).

\section{Dual culture of bacterial isolates B1, B2 and B3 and the pathogen}

As shown in Fig. (2), the isolate B1 did inhibit the mycelium growth up to 15 days with an inhibition zone of $75 \mathrm{~mm}$. On the other hand, the isolate B3 inhibited the fungus growth only until the day 10 . No inhibition could be observed for isolate B2 
Table (3) : Biochemical and cultural characterization of isolates B1, B2 and B3.

\begin{tabular}{|c|c|c|c|}
\hline Isolates & B1 & B2 & B3 \\
\hline Gram staining & Gram positive short rod & Gram positive short rod & Gram positive short rod \\
\hline Motility & + & + & + \\
\hline Catalase & + & + & + \\
\hline Aerobic growth & + & + & + \\
\hline Anaerobic growth & - & - & - \\
\hline \multicolumn{4}{|c|}{ Acid from: } \\
\hline Glucose & + & + & + \\
\hline Sucrose & + & + & + \\
\hline Fructose & + & + & + \\
\hline Mannitol & + & + & + \\
\hline Galactose & + & + & + \\
\hline Gas production & - & - & - \\
\hline \multicolumn{4}{|c|}{ Hydrolysis of: } \\
\hline Gelatin & + & + & + \\
\hline Starch & + & + & - \\
\hline Indole production & - & - & - \\
\hline Citrate utilization & + & - & + \\
\hline \multicolumn{4}{|c|}{ Growth in $\mathrm{NaCl}$ : } \\
\hline $5 \%$ & + & + & + \\
\hline $7 \%$ & + & + & + \\
\hline $10 \%$ & + & + & + \\
\hline Oxidase & + & + & + \\
\hline Nitrate reduction & + & + & - \\
\hline
\end{tabular}

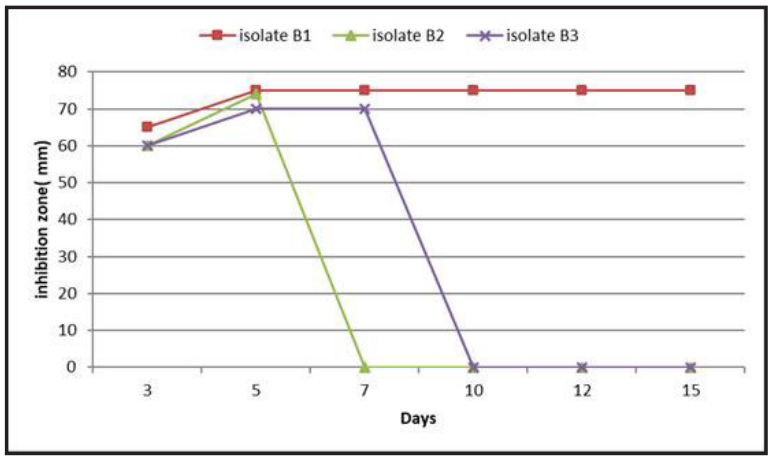

Fig. (2): Mycelium growth of $R$. solani in dual culture with the three bacterial B1, B2 and B3.

\section{Phylogenetic identification of isolate B1}

The 16S rRNA sequence was analyzed by BLAST and shown its identity with $100 \%$ sequence similarity to Bacillus sp. Furthermore, the sequence was used to build a phylogenetic tree to form its relationship with its closest identical species using blast tree view and was found to be closely related to Bacillus sp. (Fig.3) (Genbank Accession no. MK030136).

\begin{tabular}{|c|c|}
\hline & Bacillus subtilis strain M9-9 16 S ribosomal RNA gene, complete sequence \\
\hline \multirow[t]{6}{*}{0} & Bacillus sp. LB159 16 S ribosomal RNA gene, partial sequence \\
\hline & Bacillus sp. (in: Bacteria) strain HS15-1 16S ribosomal RNA gene, partial sequence \\
\hline & Bacillus sp. mkj-17 16 S ribosomal RNA gene, partial sequence \\
\hline & glel|Query_l14845 This study \\
\hline & Bacillus amyloliquefaciens strain NELB-12 16 S ribosomal RNA gene, partial sequence \\
\hline & Bacillus amyloliquefaciens strain Lac02T 16S ribosomal RNA gene, partial se. \\
\hline 0.0004 & Bacillus subtilis 16 S ribosomal RNA gene, partial sequence \\
\hline & Bacillus vallismortis strain BV23 I6S ribosomal RNA gene, partial sequence \\
\hline
\end{tabular}

Fig. (3): Phylogenetic identification of the $16 \mathrm{~S}$ rRNA subunit of the highly effective isolate B1 and its relatedness to other bacilli. 
Antagonism of Bacillus sp. on hyphae of R. solani:

\section{Microscopic examination}

The images show that the blue dye did not bind to the fungus after treatment with Bacillus sp. (Fig. $4 \mathrm{~A}$ ) as compared to a very deep blue color seen in untreated control samples (Fig. 4B).

\section{Ultrastructural examination}

Control sample (Fig. 5 A) shows that the hyphae maintained their normal and intact shape while

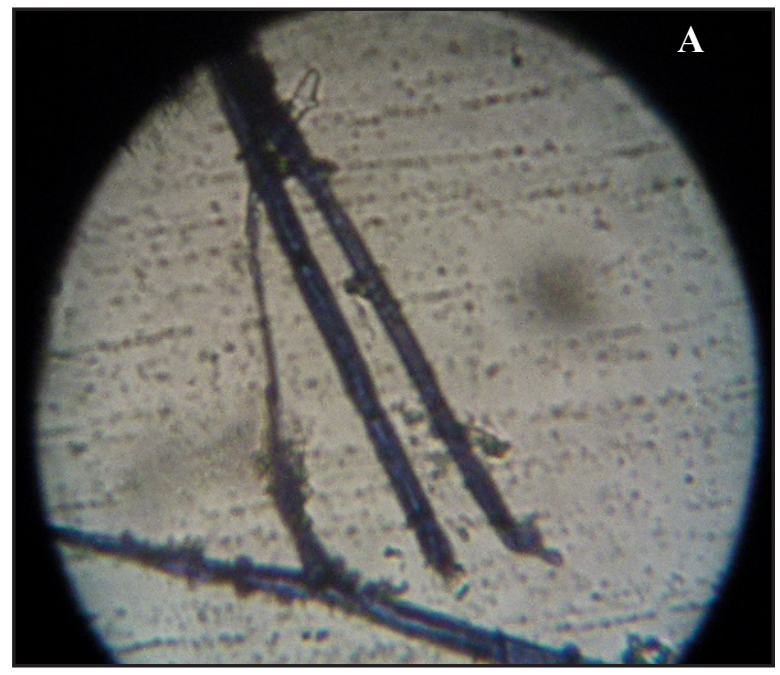

in sample treated with bacterial isolate severely changed in the appearance of hypha. The bacterial growth was adhering and colonizing the hyphae at the third day, thus leading to infusion of hyphal tissues. As a result, abnormality of fungal structures was obvious, leading to shrinking and shriveling of hyphae at the $5^{\text {th }}$ day (Fig. 5 B, C). The bacterial colonization over the hyphae resembled a slimy growth and was seen engulfing the hyphae (Fig. 5 D taken on the $7^{\text {th }}$ day).

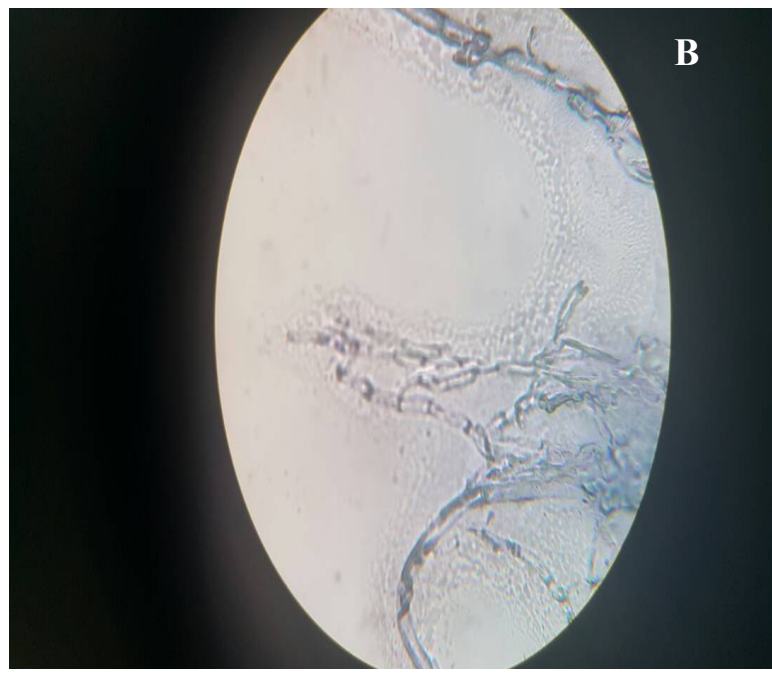

Fig. (4): Light microscope images of Rhizoctonia solani treated with Bacillus sp. (B) as compared to control samples (A). Both samples were stained with lactophenol cotton blue. Magnification using 40X lens.
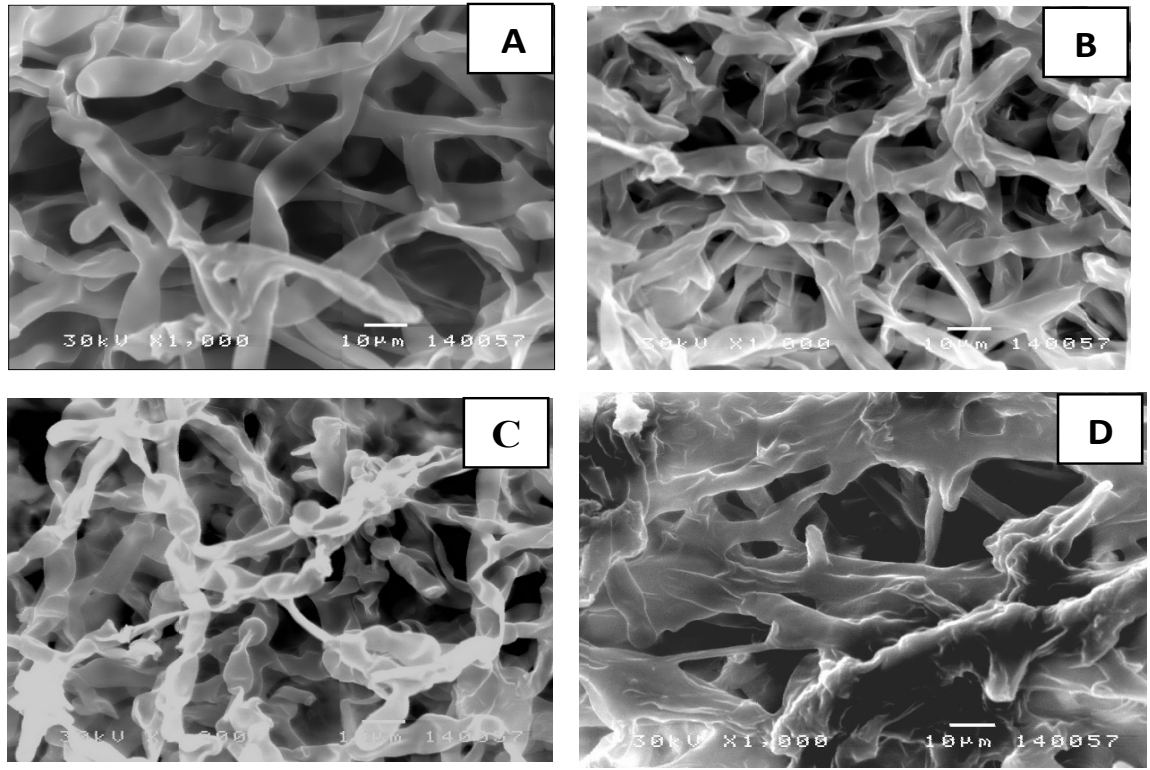

Fig. (5): Scanning electron micrographs of untreated (A) and treated hyphae (B, C and D).. 
The TEM analysis was used to estimate the structural characteristics of young hyphae treated with the biocontrol agent (Bacillus sp.). Control $R$. solani hyphae produced regular cell walls, with equal widths and distinctive layers, septa with uniform composition as well as dense cytoplasm with good distribution and clearly distinct organelles, such as nucleus and lipid body (Fig. 6 A, B). In contrast, treatment with Bacillus sp. caused significant
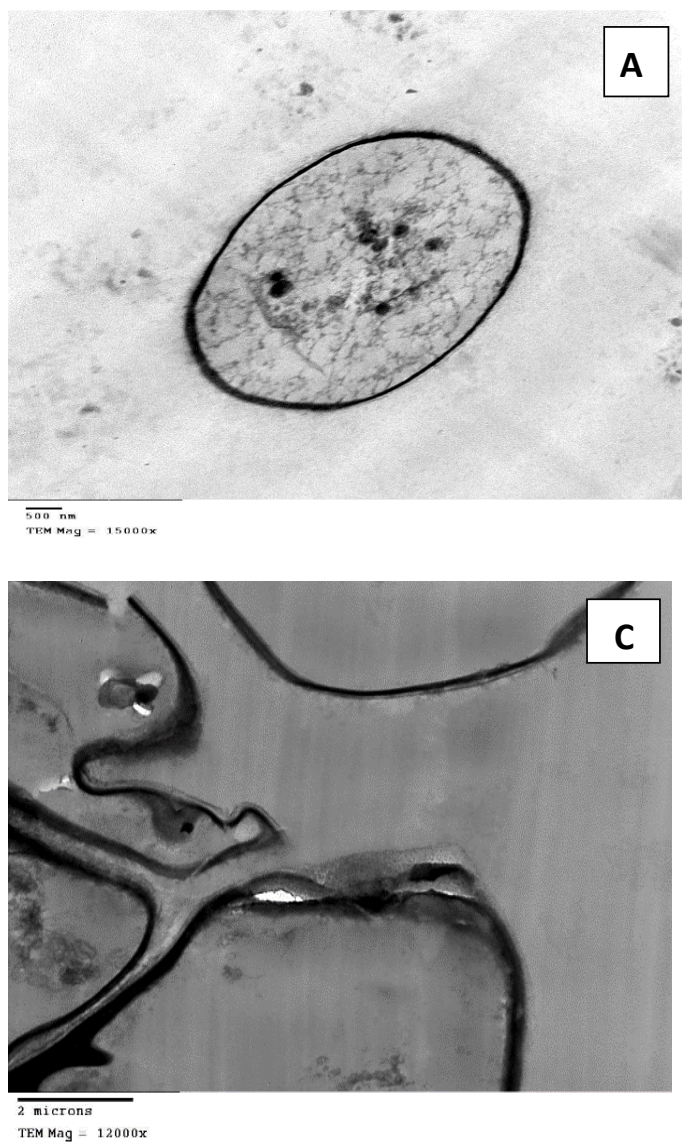

Fig. (6): Transmission electron micrographs showing transverse section of untreated hyphae cells (A) and septum (B) as compared to hyphae treated with Bacillus sp. (C) and that lacking septum (D).

Physical characteristics of adhesion of Bacillus sp. on clay nanoparticles

Bacillus sp. attached on clay nanoparticles were characterized using either SEM, XRD or FT-IR. Fig. (7 A3) shows rod - shaped Bacillus sp. aggregates adhered on surface of clay nanoparticles. The control without the bacterium (Fig. 7A1) and bacterial cells
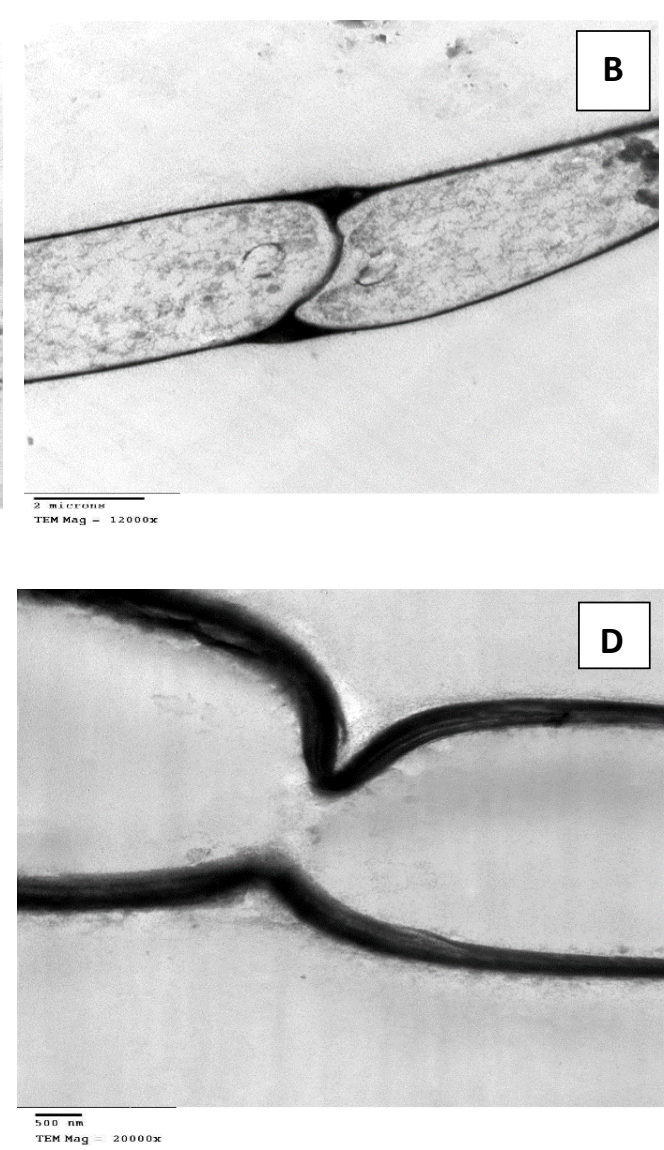

structural destruction of hyphae, especially in cell walls and plasma membranes, treated cell wall had no distinct layers. Furthermore, plasma membranes were detached from cell walls and septa. Septa had no distinct layers or structures. The damaged cell walls and membranes allowed the cell contents to leak out (Fig. 6 C, D) as compared to the control cells. 
The FT-IR spectra for the clay nanoparticles, $B a$ cillus sp. and bionanocomposite are shown in Fig. (7C). The spectrum of clay nanoparticles represents stretching vibration bands of water molecules adsorbed on clay shifted from 3450 to $3354 \mathrm{~cm}^{-1}$ and from 1633 to $1664 \mathrm{~cm}^{-1}$ after bacterial adhesion. The band located at $1658 \mathrm{~cm}^{-1}$, which is assigned to the vibration of amide I, was observed in pure Bacillus sp. spectrum. This band was shifted to $1664 \mathrm{~cm}^{-1}$ for Bacillus sp. nanocomposite.
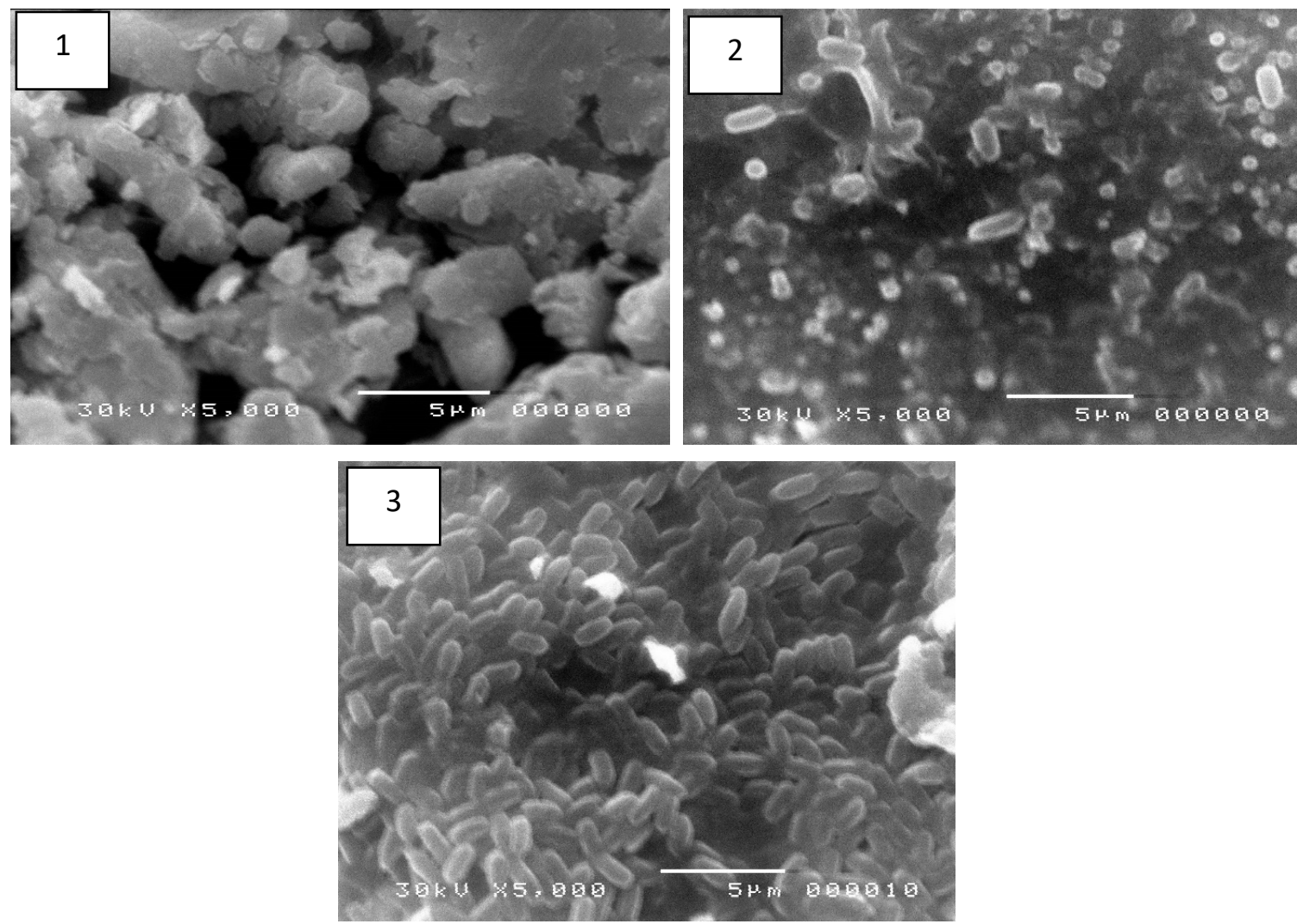

Fig. (7A): SEM images of clay nanoparticles only (1), Bacillus sp. cells (2) and Bacillus sp. adhered on clay nanoparticles (3).

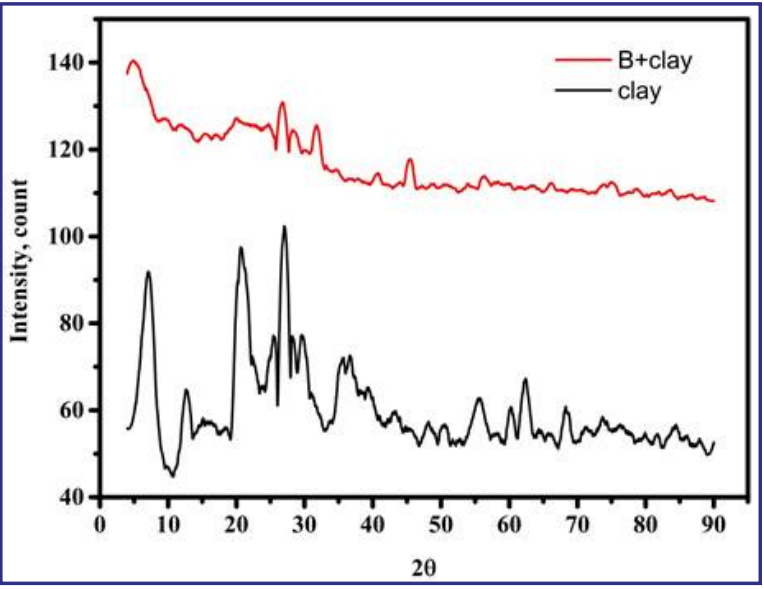

Fig. (7B): X- ray defraction (XRD) for nanoclay and bionanocomposite.

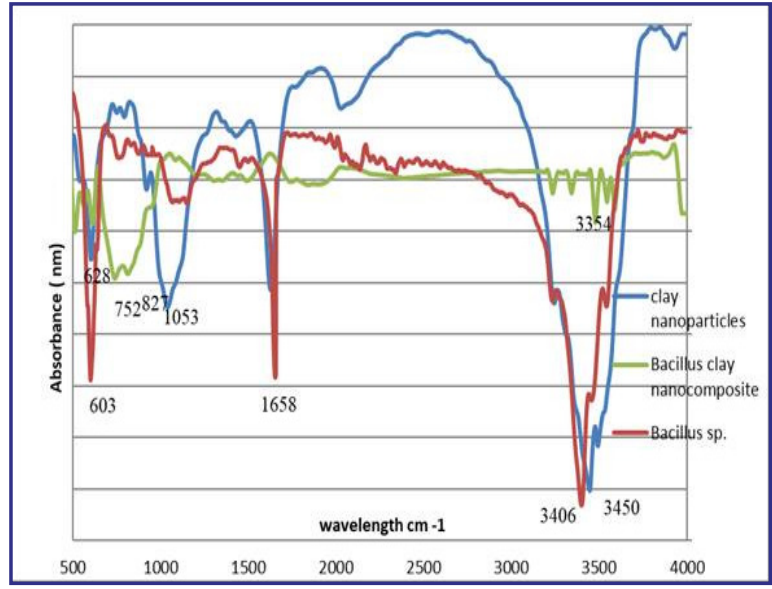

Fig. (7C): FTIR spectroscopy representing nanoclay, Bacillus and bionanocomposite of Bacillus immobilized on nanoclay. 
Shelf life of bionanocomposite and its antagonistic activity against $R$. solani

The viability of Bacillus sp. in clay nanoparticles powder (Fig. 8) showed slight decrease in counts among 7 months with significant difference $\mathrm{p}<0.05$ and the lowest viability rate was observed at $8^{\text {th }}$ month (ca. $3 \times 10^{5} \mathrm{CFU} / \mathrm{ml}^{-1}$ ). Bioactivity results of Bacillus nanocomposite exhibited high inhibition against $R$. solani (88\%) in vitro during 2-month storage period.

\section{Green house studies}

The bionanocomposite positively increased the fresh, dry weight and length of both shoots and roots over all dipping periods compared with the Bioark (positive control). At zero-time dipping, only $22 \%$ disease incidence could be observed using the bionano composite, compared with $66 \%$ with the Bio ark (Table 4).

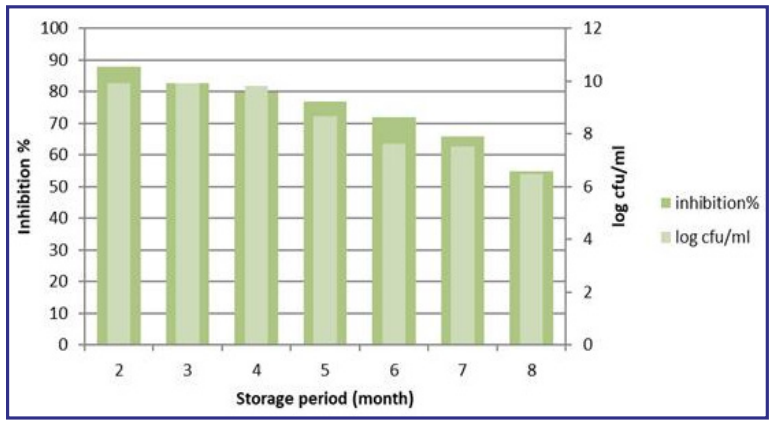

Fig. (8): Viability and bioactivity of bionanocomposite on radial growth rate of R.solani during different storage periods.

Table (4) : Effects of various treatments on fresh and dry weights $(\mathrm{g})$, length (cm) of roots and shoots of potato infected by $R$. solani.

\begin{tabular}{|c|c|c|c|c|c|c|c|c|}
\hline \multirow[b]{2}{*}{ Treatments } & \multirow{2}{*}{$\begin{array}{c}\text { Immersion } \\
\text { time }\end{array}$} & \multicolumn{3}{|c|}{ Root } & \multicolumn{3}{|c|}{ Shoot } & \multirow{2}{*}{$\begin{array}{c}\% \\
\text { Disease } \\
\text { incidence }\end{array}$} \\
\hline & & $\begin{array}{l}\text { Fresh } \\
\text { weight }\end{array}$ & $\begin{array}{c}\text { Dry } \\
\text { weight }\end{array}$ & Length & $\begin{array}{l}\text { Fresh } \\
\text { weight }\end{array}$ & $\begin{array}{c}\text { Dry } \\
\text { weight }\end{array}$ & Length & \\
\hline $\begin{array}{l}\text { Infested } \\
\text { (negative } \\
\text { control) }\end{array}$ & & 0.4 & 0.07 & 3.5 & 16 & 1.5 & 10.3 & 100 \\
\hline \multirow{5}{*}{$\begin{array}{c}\text { BIOARK } \\
\text { (positive control) }\end{array}$} & zero time & $1.23^{\mathrm{e}}$ & $0.32^{\mathrm{g}}$ & $6.2^{\mathrm{h}}$ & $14.87^{j}$ & $2.23^{g}$ & $16.3^{\mathrm{g}}$ & 66 \\
\hline & $10 \mathrm{~min}$ & $1.23^{\mathrm{e}}$ & $0.41^{\mathrm{f}}$ & $7.67^{\mathrm{g}}$ & $18.67^{\mathrm{i}}$ & $2.53^{\mathrm{g}}$ & $17.3^{\mathrm{g}}$ & 44 \\
\hline & $20 \mathrm{~min}$ & $1.37^{\mathrm{de}}$ & $0.47^{\mathrm{f}}$ & $8.60^{\mathrm{fg}}$ & $20.03^{\mathrm{h}}$ & $3.13^{\mathrm{f}}$ & $18.53^{\mathrm{f}}$ & 33 \\
\hline & $30 \mathrm{~min}$ & $1.57^{\mathrm{bcd}}$ & $0.59^{\mathrm{e}}$ & $9.03^{\mathrm{ef}}$ & $20.93^{\mathrm{g}}$ & $3.46^{\mathrm{ef}}$ & $19.13^{\text {ef }}$ & 11 \\
\hline & $60 \mathrm{~min}$ & $1.77^{\mathrm{ab}}$ & $0.69^{\mathrm{d}}$ & $9.93^{\mathrm{e}}$ & $24.43^{\mathrm{f}}$ & $4.07^{\mathrm{d}}$ & $19.83^{\mathrm{e}}$ & 0 \\
\hline \multirow{5}{*}{$\begin{array}{l}\text { Bionano } \\
\text { composite }\end{array}$} & zero time & $1.47^{\mathrm{cd}}$ & $0.59^{\mathrm{e}}$ & $12^{\mathrm{d}}$ & $28.9^{\mathrm{e}}$ & $3.90^{\mathrm{de}}$ & $29.50^{\mathrm{d}}$ & 22 \\
\hline & $10 \mathrm{~min}$ & $1.57^{\mathrm{bcd}}$ & $0.69^{d}$ & $17.83^{\mathrm{c}}$ & $34.07^{\mathrm{d}}$ & $5.47^{\mathrm{c}}$ & $33.83^{c}$ & 11 \\
\hline & $20 \mathrm{~min}$ & $1.63^{\mathrm{bc}}$ & $0.9^{\mathrm{c}}$ & $19.50^{\mathrm{b}}$ & $36.13^{c}$ & $6.23^{b}$ & $36.5^{\mathrm{b}}$ & 0 \\
\hline & $30 \mathrm{~min}$ & $1.87^{\mathrm{a}}$ & $1.17^{\mathrm{b}}$ & $19.83^{\mathrm{b}}$ & $37.13^{b}$ & $6.73^{\mathrm{a}}$ & $40^{\mathrm{a}}$ & 0 \\
\hline & $60 \mathrm{~min}$ & $1.97^{\mathrm{a}}$ & $1.39^{\mathrm{a}}$ & $21.17^{\mathrm{a}}$ & $40.83^{a}$ & $6.90^{\mathrm{a}}$ & $39.9^{\mathrm{a}}$ & 0 \\
\hline
\end{tabular}

Means with the same letters of the same assessment are not significantly different $(P=0.05)$

\section{DISCUSSION}

A total of eighty -four bacterial isolates was isolated from healthy potato plants collected from different areas of Egypt. Antagonism of all isolates was first evaluated against $R$. solani by adopting dual culture assay. On the basis of these tests, three efficient antagonistic bacteria i.e., B1, B2, B3 were selected and belonged to the genus Bacillus and significantly controled $R$. solani. The inhibition efficiencies recorded were 83, 78 and $82 \%$, respectively. These inhibition capabilities were apparently higher than those observed by other researches such as EI Ben- 
dary et al. (2016) using B. subtilis (40\%) or Bacillus 29 Es (70\%). It was reported that the production of protease enzyme and antifungal compounds by $\mathrm{Ba}$ cillus are directly related to fungal growth inhibition because of the ability of Bacillus to degrade fungal cell wall and disrupt its internal organelles (Ben Khedher et al., 2015). Only the isolate B1 produced hydrogen cyanide, which was reported to block the cytochrome oxidase pathway and is highly toxic to aerobic microorganisms at low concentrations (Kumar et al., 2012). The Isolates B1 and B3 produced siderophores which are known to chelate most of the available iron thus preventing the proliferation of the pathogen due to lack of the iron (Bharucha et al., 2013). In addition to being the only isolate producing hydrogen cyanide, isolate B1 was the only one that produced indole acetic acid (IAA). IAA is considered important for plant growth promotion, enhancing nutrient uptake and effectively colonizing the rhizosphere (Jadhav et al., 2017). The isolate B1 generated a fungicidal effect in solid culture medium. In agreement with these results. Torres $\boldsymbol{e t} \boldsymbol{a l}$. (2017) observed that the metabolites produced by Bacillus amyloliquefaciens PGPBacCA1 generated a fungicidal effect in solid culture medium. On the other hand, the isolates B2 and B3 only caused a fungistatic effect on this pathogen. A possible explanation can be associated to the low concentration or even the absence of the active antifungal compound in the narrow interface between the fungal mycelium and the bacterial colony. Moreover, the antagonistic effect produced by these strains may also be related to a competition for space or nutrients, instead of a fungicidal effect due to antifungal bacterial metabolites. Phylogenetic analysis revealed that the isolate B1 is closely related to Bacillus sp. Light microscope images of cotton blue stained fungus before and after treatment with Bacillus sp. showed that the blue dye did not bind to the fungus after its treatment as compared to a very deep blue color seen in untreated control samples. Lactophenol cotton blue is a dye used for staining as well as for wet mounting of fun- gi, cotton blue imparts blue colouration to the fungal spores and hyphae, its lack of binding indicates the disruption of fungal hyphae, lysis, and abnormalities such as abnormal enlargement of hyphae, terminal swelling, wrinkling and shrinking of hyphae (Parija and Prabhakar, 1995). The effect of Bacillus sp. on the morphological structure of fungal hyphae observed by SEM indicate that the mode of action of Bacillus sp. against $R$. solani includes two forms of antagonism, e.g. antibiosis and parasitism. Loss of structural integrity of pathogen hyphae due to antibiosis of Bacillus sp. was observed. Hyper-parasitism on fungal hyphae was evident through maceration, shrinking, shriveling and abnormal coiling (Kumar et al., 2012). TEM analysis showed that Bacillus sp. caused significant structural destruction of hyphae, especially in cell walls and plasma membranes, treated cell wall had no distinct layers. Furthermore, plasma membranes were detached from cell walls and septa. Septa had no distinct layers or structures. The damaged cell walls and membranes allowed the cell contents to leak out. These results agree with the findings of Gong et al. (2015) as the clay particles possess a high specific surface area and cationic exchange capacity which combine to create a high adsorption capacity, the attachment of microbial cells on clay particles includes both electrostatic and non-electrostatic mechanisms. In the electrostatic interaction, the cationic surface of clay particles attracts the negatively charged cell walls of Gram-positive bacteria due to presence of proton active functional groups as hydroxyl and amide group (Tourney and Ngwenya, 2014). The non-electrostatic mechanisms mainly include hydrogen bonding, Van der Waals forces and hydrophobic interaction. The attachment of cells onto clay minerals can be influenced by the production of extracellular polymeric substance that increases the attachment of bacteria on clay due to their polymeric interaction. In this regard, clay nanoparticles are efficient support materials and provide a protective habitat for microorganisms by forming biofilm. These results agree 
with the findings of Fathima et al. (2012). The peaks in XRD patterns representing clay nanoparticles exhibited change in their intensities. This can be attributed to the coverage of the clay nanoparticles with Bacillus sp. These findings are in agreement with Biswas et al. (2017) who showed that the insertion of other organic molecules (EPS and other macromolecules produced by the bacterial activity), leads to slight increase of basal space of montmorillonite and a higher production of these compounds might have a significant impact in the interlayer structure. The FT-IR spectra for the clay nanoparticles in the present study represent stretching vibration bands of water molecules adsorbed on clay shifted from 3450 to $3354 \mathrm{~cm}^{-1}$ and from 1633 to $1664 \mathrm{~cm}^{-1}$ after bacterial adhesion. These results suggest that the water molecules adsorbed on the clay minerals are involved in bacterial adhesion. The shifted frequencies have been assigned to hydrogen bonding interactions between the bacterial cell components and water molecules at clay surfaces (Tavanaei et al., 2017). In Bacillus sp. nanocomposite spectrum represents conformational or orientation changes of cell surface proteins upon interaction with the fibrous clays. Tavanaei et al. (2017) showed the same band of pure $P$. putida spectrums $\left(1658 \mathrm{~cm}^{-1}\right)$ and was shifted to $1657 \mathrm{~cm}^{-1}$ and $1648 \mathrm{~cm}^{-1}$ for $P$. putida-palygorskite and $P$. putida-sepiolite complexes, respectively. Nano clay as a carrier plays an important role in $\mathrm{Ba}$ cillus formulation to make it applicable under field conditions, elongate the shelf life and commercially appropriate. Also, they have a high aspect ratio that affords more interactive surfaces when exfoliated and dispersed well. Clays have been exploited for immobilization due to their mechanical and thermal stabilities, chemical inertness, well defined layered structures and ion exchange properties (Ghormade et al., 2011). Most formulations maintained bacterial viability until 6 months of storage at $22^{\circ} \mathrm{C}$ when they used talc as the carrier material (Klein et al 2016). According to Ya et al. (2012), commercial products should have at least 6 months of shelf life and a pref- erence to be stored at room temperature. The greenhouse experiment in the present study proved the biocontrol ability of the bionanocomposite against R. solani. Indeed, potato tuber (seeds) treatment with bionanoconpsite formulation significantly suppressed $R$. solani growth and enhanced plant growth, when compared to the untreated plants. Likewise, Idris et al. (2009) reported that Bacillus strains significantly enhanced plant growth and inhibited soilborne pathogen when using an antagonist-treated tuber. On the other hand, coating of tomato seeds with B. subtilis RB14-C did not protect tomato plants against $R$. solani. (Szczech et al., 2006). Consequently, the efficacy of seed inoculation with $B$. subtilis was not established for all model plants. Bionanocomposite was able to control stem canker $(100 \%$ biocontrol efficacy) more efficiently than the commercial biofungicides BioARK at different immersion times. Tariq et al. (2010) reported that Pseudomonas spp. StT2 and StS3 reduced the proportion of infected tubers by $R$. solani to $40 \%$ for cv. Spunta and to $74 \%$ for $\mathrm{cv}$. Nicola. In addition to its ability to protect potato plants against $R$. solani more efficaciously than Pseudomonas spp., Bacillus sp. has the advantage to form endospores that facilitate its production and recovery at a large scale, its formulation and its use in pots and in field treatments. Moreover, Bacillus sp. significantly promoted the growth of potato plants. Indeed, bionanocomposite inoculation into potato tuber in the presence of the pathogen increased the height and the weight of stems, and the weight of roots significantly, in comparison to the untreated control. The advancement of plant growth can involve direct and indirect mechanisms. Direct growth promotion is due to bacterial secretion of phytohormones and metabolites that can influence root by overproduction of root hairs and lateral roots and then increase nutrient and water uptake, thus participating to growth. The indirect promotion of plant growth can be due to antibiosis, competition for space and nutrients, parasitism or lysis of pathogen hyphae, inhibition of pathogen-produced en- 
zymes or toxins, and through induced systemic resistance. (Ben khedher et al., 2015). Taking into account the harmful effect of Bacillus sp. on fungus hyphae. This suggests that the promotion of plant growth by bionanocomposite may be mainly associated with direct and indirect effect, also clay nanoparticles are ideal for maintaining survival and viability of Bacillus sp. and rapid adhesion with colonization of clay nanoparticles.

\section{CONCLUSION}

An important perspective of the present study is the isolation of Bacillus sp. that has a strong antifungal activity against Rhizoctonia solani. This bacterium produces an array of metabolites, each playing an important role in the antagonism process ensuring a highly effective and prolonged control as compared to other available bacteria. This bacterium and its metabolites also provide an attractive option for sustainable agriculture due to their ability to stimulate plant growth and production. Preparing the biocontrol agent as a nanocomposite formulation increases its efficiency and longevity, thus providing a safe and effective alternative to traditional commercial formulations.

\section{REFERENCES}

- $\quad$ Adhikari, A.; Dutta, S.; Nandi, S.; Bhattacharya, I.; DeRoy, M.; Sarkar, G.; Mandal, T. (2013): Antagonistic potentiality of native rhizobacterial isolates against root rot disease of okra, incited by Rhizoctonia solani. Afr. J. Agric. Res., 8(4): 405.

- Ajayi-Oyetundea, O.O. and Bradley, C.A. (2018): Rhizoctonia solani: taxonomy, population biology and management of rhizoctonia seedling disease of soybean. Plant Pathol., 67: 3.

- Ben Khedher, S.; Kilani-Feki,O. ;Dammak, M. ; Khiareddine, H. ; Remadi, M. ; Tounsi, S. ( 2015): Efficacy of Bacillus subtilis V26 as a biological control agent against Rhizoctonia solani on potato. J. Plant Biol Pathol., 1631.
- $\quad$ Bharucha, U.; Patel, K.; Trivedi, U. (2013): Optimization of Indole Acetic Acid Production by Pseudomonas putida UB1 and its Effect as Plant GrowthPromoting Rhizobacteria on Mustard (Brassica nigra). J. Agri. Res. 2249.

- Biswas, B.; Chakraborty, A.; Sarkar, B.; Naidu, R. (2017): Structural changes in smectite due to interaction with a biosurfactant-producing bacterium Pseudoxanthomonas kaohsiungensis. J. Appl. Clay Sci., 136: 51.

- Chaurasia, B. ; Pandey, A. ; Palni, L. ; Trivedi, P. ; Kumar, B. ;Colvin, N. ( 2005): Diffusible and volatile compounds produced by an antagonistic Bacillus subtilis strain cause structural deformations in pathogenic fungi in vitro. Microbiol. Res., 160: 75.

- $\quad$ Edwards, U.; Rogalt, T.; Blocker, H.; Emde, M.; Bottger, E. C. (1989): Isolation and direct complete nucleotide determination of entire genes, characterization of a gene coding for $16 \mathrm{~S}$ ribosomal RNA. $J$. Nucleic Acid Res., 19: 7843.

- $\quad$ El-Bendary, M.; Hamed, H.; Moharam, M. (2016): Potential of Bacillus isolates as bio-control agents against some fungal phytopathogens. J. Biocat. Agricul. Biotechnol., 5: 173.

- $\quad$ FAO report. (2009): International year of the potato 2008: ew light on hidden treasure. http://www. fao.org/potato-2008/ en /events book.html accessed8 Aug 2014.

- $\quad$ FAO (2014): FAO statistical databases FAOSTAT. http://faostat3.fao.org.

- $\quad$ Fathima, A.; Rao, J.R.; Nair, B.U. (2012): Trivalent chromium removal from tannery effluent using kaolin-supported bacterial biofilm of Bacillus sp. isolated from chromium polluted soil. J. Chem. Technol. Biotechnol. 87: 271.

- Ghormade,V. ; Deshpande, M. V. ; Panikar, K. M. (2011): Perspectivees for nano-biotechnology enabled protection and nutrition of plants. Biotechnol. Adv., 29: 792. 
- Gong, A.; Li, H.; Yuan, Q.; Song, X.; Wei, W.; He, J.; Zhang, J.; Liao, Y. (2015): Antagonistic Mechanism of Iturin A and Plipastatin A from Bacillus amyloliquefaciens S76-3 from Wheat Spikes against Fusarium graminearum. PLoS ONE 10(2): e0116871.

- Gordon, S.A; Weber, R.P. (1951): Colorimeteric estimation of indole acetic acid. Plant Physiol., 26: 192.

- Idris, A.; Labuschagne,N. ; Korsten,L. ; (2009): Efficacy of rhizobacteria for growth promotion in sorghum under greenhouse conditions and selected modes of action studies, J. Agric. Sci., 147: 17.

- Jadhav, H.P.; Shaikh, S.S.; Sayyed, R.Z. (2017): Role of hydrolytic enzymes of rhizofora in biocontrol of fungal phytopathogens: an overview. In: Mehnaaz S (ed) Rhizotrophs: plant growth promotion to bioremediation. J. Singapore, 183.

- Jamalizadeh, M.; Etebrian, H.R.; Aminian, H.; Alizidah, A. (2011): A review of mechanisms of action of biological control organisms against postharvest fruit spoilage. J. Bulletin., 41: 65.

- Klein, M. N.; da Silva1, A.C.; Kupper, C.K. (2016): Bacillus subtilis based-formulation for the control of postbloom fruit drop of citrus. World J Microbiol Biotechnol., 32 .

- Kumar, G.P.; Kishore, N.; Amalraj, E.L.D.; Ahmed, S.K.M.H.; Rasul, A.; Desai, S. (2012): Evaluation of fluorescent Pseudomonas spp. with single and multiple PGPR traits for plant growth promotion of sorghum in combination with AM fungi. $J$. Plant Growth Regulat., 67: 133.

- Kumar, K.; Yellareddygari, S.; Reddy, M.S.; Kloepper, J.W.; Lawrence, K.S.; Miller, M. E.; Sudini, H.; Reddy, E.; Zhou, X. G.; Groth, D.E. (2013): Ultrastructural studies on the interaction between Bacillus subtilis MBI 600 (Integral) and the rice sheath blight pathogen, Rhizoctonia solani. African J. Microbiol. Res., 7(19): 2078.

- Kumar, M.; Singh J.; Kumar, S.; Kumar, A. (2017): A Comprehensive Overview on Black Scurf of Potato. Int. J. Curr. Microbiol. App. Sci., 6(10): 4981.

- Ma, X.; Wang, X.; Cheng, J.; Nie, X.; Yu, X.; Zhao, Y.; Wang, W. (2015): Microencapsulation of Bacillus subtilis B99-2 and its biocontrol efficiency against Rhizoctonia solani in tomato. Biol. Control., 90: 34 .

- Montealegre, J.; Rodrigo, R.; María, L.; Herrera, R. (2003): Selection of bioantagonistic bacteria to be used in biological control of Rhizoctonia solani in tomato. J. Biotechnol., 6: 115.

- Nandi, M.; Selin, C.; Brawerman, G.; Fernando, W.G.; de Kievit. T. (2017): Hydrogen cyanide, which contributes to Pseudomonas chlororaphis strain PA23 biocontrol, is upregulated in the presence of glycine. J. Biol. Control., 108: 47.

- Raupach, G.S.; Kloepper, J.W. (1998): Mixtures of plant growth-promoting rhizobacteria enhance biological control of multiple cucumber pathogens. $J$. phytopathol., 88: 1158.

- Parija, S.C.; Prabhakar, P.K. (1995): Evaluation of Lacto-Phenol Cotton Blue for Wet Mount Preparation of Feces. J. clinical microbiology, 1019.

- Patten C.L.; Glick, B.R. (2002): Role of Pseudomonas putida indole acetic acid in development of the host plant root system. J. Appl. Environ. Microbiol. 68: 3795.

- Shafi, J.; Tian, H.; Ji, M. (2017): Bacillus species as versatile weapons for plant pathogens: a review. $J$. Agri Environ Biotechnol., 31: 446.

- Shanmuga, P. K.; Gnanamani, A.; Radhakrishnan, N.; Babu, M. (2002): Antimicrobial activity of Datura alba. J. Indian Drugs, 39: 113.

- $\quad$ Sneath, P. H. A.; Mair, N. S.; Sharpe, M. E.; Holt, J. G. (1986): Bergey's Manual of Systematic Bacteriology, Vol. 2. Baltimore: Williams \& Wilkins.

- Szczech, M.; Shoda, M. (2006): The effect of mode of application of Bacillus subtilis RB14-C on its effi- 
cacy as a biocontrol agent against Rhizoctonia solani, J. Phytopathol., 154: 370.

- $\quad$ Tavanaei, M.; Shirvani, M.; Bakhtiary, S. (2017): Adhesion of Pseudomonas putida onto Palygorskite and Sepiolite Clay Minerals. J. Geomicrobiology., 34: 677 .

- Tariq, M.; Yasmin, S.; Fauzia, Y.H. (2010): Biological control of potato black scurf by rhizosphere associated bacteria, Braz. J. Microbiol., 41: 439.

- Thakaew, R.; Niamsup, H. (2013): Inhibitory activity of Bacillus subtilis BCC 6327 metabolites against growth of aflatoxigenic fungi isolated from Bird Chili Powder. Int. J. Biosci. Biochem. Bioinforma., 3: 27.

- Torres, M.; Brandan, C.; Sabaté, D.; Petroselli, G.; Balsells, R.; Audisio, M. (2017): Biological activity of the lipopeptide-producing Bacillus amyloliquefaciens PGPBacCA1 on common bean Phaseolus vulgaris L. pathogens. J. Biol. Control., 105: 93.

- $\quad$ Tortora, M.; Dı'az-Ricci, J.; Pedraza, R. (2011): Azospirillum brasilense siderophores with antifungal activity against Colletotrichum acutatum. J. Arch. Microbiol., 193: 275.
- Tourney, J.; Ngwenya, B. T. (2014): The role of bacterial extracellular polymeric substances in geomicrobiology. Chem. Geol., 386: 115.

- Ya'nez-Mendiza'bal, V.; Viñ̃as, I.; Usall, J.; Torres, R.; Solsona, C.; Abadias, M.; Teixido, O. (2012): Formulation development of the biocontrol agent Bacillus subtilis strain CPA-8 by spray- drying. J. Appl Microbiol., 112: 954.

- Yang, H.; Sung, Y. (2011): Biocontrol of mildew with Bacillus subtilis in bitter gourd (Momordica charantia L.) seeds during germination. J. Scientia Horticulturae., 130: 38.

- $\quad$ Zhang, B.; Dong, C.; Shang, Q.; Han, Y.; Li, P. (2013): New insights into membrane - active action in plasma membrane of fungal hyphae by the lipopeptide antibiotic bacillomycin L. J. Biochim. et Biophys. Acta 1828: 2230. 
